\title{
Effect of Domestic Saving on Capital Formation in Kenya
}

\author{
Mukhongo Wafula $^{1^{*}}$ Nelson Obange ${ }^{1} \quad$ Alphonce Odondo ${ }^{2}$ \\ 1.School of Business and Economics, Maseno University, PO box Private Bag, Maseno, Kenya \\ 2.School of Business and Economics, Tom Mboya University, PO box 199-40300 Homa Bay, Kenya
}

\begin{abstract}
Kenya's average rate of gross capital formation of 20.13\% of GDP over the period 2006-2017 falls short of at least $25 \%$ necessary for developing countries to experience sustainable growth. The attendant effects of low capital formation have entrenched unemployment rate above 39\% line and consigned more than 65 per cent of the country's population to living on less than $\$ 2$ a day. The statistics suggest the need for urgent policy intervention aimed at accelerating capital formation in Kenya. But whether the government should respond by mobilizing more domestic saving or not is the question which this study sought to answer. This is because majority of the previous studies that investigated the effects of domestic saving on development indicators limited themselves to growthsaving nexus. Those that investigated the effect of domestic saving on capital formation either restricted themselves to a bivariate framework or controlled for a few sources of capital formation. This implies that the effect of domestic saving on capital formation is not clear. Besides, the response of capital formation to shocks in domestic saving is not clear. The purpose of this study was to investigate the effect of domestic saving and the response of capital formation to shocks in domestic saving. The study was anchored by Solow's capital accumulation model within a correlational studies research design. Data over 1974-2017 period was sourced from the World Bank. ARDL bounds test found the existence of cointegrating relationship among gross capital formation, gross domestic saving and the controlled variables when gross capital formation was specified as the target variable. The short-run dynamic model estimates indicated that ECM term corrects $39.56 \%$ of deviations from long run equilibrium in one year. ARDL estimation indicated that in the long run, gross domestic saving has positive significant effect on gross capital formation. The results were robust for IRFs analysis which found the response of gross capital formation to innovations in gross domestic saving to be positive and significant. The study concluded that in the long-run, Kenya's capital formation will be driven by domestic saving. Therefore, to achieve high capital formation in the long-run, the study recommended policies that enhance positive effects of domestic saving for consideration by the government of Kenya.
\end{abstract}

Keywords: Kenya, Capital Formation, Domestic Saving

DOI: $10.7176 / \mathrm{JESD} / 10-16-17$

Publication date: August $31^{\text {st }} 2019$

\section{Introduction}

Low capital formation in developing countries and the search for its solution has been a dominant theme in academic and policy discussions for centuries since the inquiry into the sources of the wealth of nations by Smith (1776). Defined as the accumulation of production stock and inventories and expenditure on human capacity building (Kuznets, 1955), deficiency in capital formation is said to be the main hindrance to the development of the underdeveloped (Nurkse, 1953). According to Lewis (1954) and Kuznets (1955), capital formation is a critical factor in the transformation of an economy from a less developed to a developed one. Citing the 'growth miracles' of China and Japan and the Newly Industrializing Countries (NICs) of East Asian Tiger economies of Singapore, Malaysia, South Korea, Hong Kong and Taiwan, Krugman (1994) and Stiglitz (1996) demonstrated how capital formation can transform an economy's growth from a low path to a higher one within a very short period of time. The United Nations (2006) supports the views of development economists, affirming that structural transformation towards high productivity in developing countries cannot be possible without sufficient capital formation. The foregoing views resonate with the neoclassical growth model (Solow-Swan, 1956) and the new endogenous model (Lucas, 1988; Romer, 1990) which indicate that capital formation has positive impact on productivity. Therefore one can infer that capital formation promoting strategies are also development enhancing. It implies that any developing country that aspires to achieve high economic growth and sustainable development should prioritize enhancing capital formation process on her development agenda. 
Table 1: Evolution of Kenya's gross capital formation (\% of GDP) within the context of Sub-Saharan Africa, 2006-2017.

\begin{tabular}{|l|l|l|l|l|l|l|l|l|l|l|l|}
\hline & MWI & TGO & KEN & RWA & CMR & UGA & BFA & CR & TZA & BWA & NER \\
\hline 2006 & 20.0 & 15.7 & 18.6 & 16.1 & 21.0 & 21.1 & 20.7 & 21.6 & 26.0 & 25.9 & 23.6 \\
\hline 2007 & 23.1 & 13.4 & 20.5 & 18.2 & 20.8 & 22.1 & 22.3 & 21.8 & 32.9 & 30.8 & 22.9 \\
\hline 2008 & 23.2 & 16.6 & 19.6 & 23.3 & 24.1 & 23.0 & 25.4 & 18.3 & 32.1 & 36.2 & 32.2 \\
\hline 2009 & 24.5 & 16.9 & 19.3 & 22.6 & 23.7 & 25.0 & 24.9 & 22.5 & 25.1 & 38.9 & 34.9 \\
\hline 2010 & 22.8 & 17.5 & 20.8 & 22.3 & 23.2 & 25.6 & 26.9 & 20.5 & 27.3 & 41.4 & 40.0 \\
\hline 2011 & 12.4 & 17.7 & 21.7 & 22.5 & 24.1 & 27.5 & 28.0 & 25.3 & 33.2 & 38.6 & 38.4 \\
\hline 2012 & 12.1 & 24.2 & 21.5 & 24.8 & 22.8 & 27.3 & 32.5 & 26.0 & 28.5 & 38.8 & 36.2 \\
\hline 2013 & 12.7 & 23.2 & 20.1 & 25.4 & 23.1 & 28.4 & 32.5 & 30.9 & 30.3 & 29.4 & 36.2 \\
\hline 2014 & 12.0 & 22.7 & 22.4 & 24.4 & 24.1 & 27.3 & 25.9 & 41.3 & 30.1 & 27.9 & 37.4 \\
\hline 2015 & 12.2 & 20.3 & 21.5 & 25.8 & 22.4 & 24.6 & 24.3 & 40.9 & 27.2 & 32.1 & 38.7 \\
\hline 2016 & 10.8 & 22.5 & 17.3 & 25.3 & 22.6 & 25.5 & 20.8 & 27.8 & 25.1 & 28.6 & 31.9 \\
\hline 2017 & 13.4 & 26.7 & 18.2 & 22.9 & 22.9 & 23.7 & 22.8 & 22.6 & 26.1 & 28.1 & 33.7 \\
\hline AVE & 16.6 & 19.8 & 20.1 & 22.8 & 22. & 25.1 & 25.6 & 26.6 & 28.7 & 33.1 & 33.8 \\
\hline
\end{tabular}

Source: World Development Indicators, January 2019

Key: BFA: Burkina Faso, BWA: Botswana, CMR: Cameroon, CR: Congo Republic, KEN: Kenya, MWI: Malawi, NER: Niger, RWA: Rwanda, TZA: Tanzania, UGA: Uganda

Table 1 shows that Kenya's average rate of gross capital formation ( $\%$ of GDP) outperformed Malawi and Togo over the sub-sample period. However, it substantially lags behind SSA low income countries such as Uganda, Burkina Faso, Tanzania and Niger in the region over the same sub-sample period. It also compares poorly against fellow lower middle income country (LLMICs) such as Cameroon and Congo Republic.

This study was concerned that Kenya's average rate of capital formation of $20.13 \%$ of GDP falls short of 25 per cent of GDP required for developing countries to grow at self-sustainable rate (Geiger, 1990). The attendant effects of low capital formation have entrenched unemployment rate above 39\% line and consigned more than 65 per cent of the country's population to living on less than \$ 2 a day (World Bank, 2016a; World Bank, 2016b). The statistics suggest the need for an urgent policy intervention aimed at accelerating capital formation process in Kenya. But whether the government should respond by deploying strategies that favour the mobilization of domestic saving or not is the question which this study sought to answer. This is because majority of the studies that investigated the effect of domestic saving on development indicators limited themselves to growth-saving nexus (Ciftcioglu, \& Begovic, 2010; Misztal, 2011; Seng, 2014; Elias \& Worku, 2015). Those that attempted to investigate the effect of domestic saving on capital formation either restricted themselves to a bivariate framework (Bordoloi, 2008) or controlled for a few capital financing variables (Mbaluku, 2011; Lucky \& Uzah, 2016). This implies that the effect of domestic saving on economic growth via capital formation channel is not clear. Besides, the response of capital formation to shocks in domestic saving is not clear. Thus, the purpose of this study was to investigate the effect of domestic saving and the response of capital formation to shocks in domestic saving.

In fulfilling its purpose, this study resonated with the work of Mbaluku (2011) in Kenya. That is, it retained saving as the variable of interest and controlled for FDI. However, it distinguished itself from the work of Mbaluku (2011) in three important respects. Firstly, it further controlled for other sources of capital: diaspora remittance, multilateral aid and bilateral aid. Secondly, it updated the dataset in order to reflect the recent episodes of surges and downturns in domestic saving in Kenya. Lastly, it employed the dynamic ARDL approach which takes into account the current and lagged effects of domestic saving on capital formation.

This study contributes to policy direction by providing the answer to the policy relevant question of whether the government of Kenya should respond to the problem of low capital formation by deploying strategies that favour the mobilization of domestic saving or not. It also contributes to advancing scholarship on capital formation by: testing the validity of existing theories and providing an empirical perspective to the current animated debate by the academic intelligentsia on whether it is time for Africa to declare to the West that it no longer requires her donations.

\section{Literature Review}

\subsection{Cross-Country Studies}

Feldstein \& Horioka (1980) specified a linear relationship between domestic investment to GDP and national saving to GDP in their empirical investigation of capital mobility. Using data from sixteen Organization for Economic Cooperation and Development (OECD) countries for the period 1960 to 1974, the two-stage least squares (2SLS) estimation finds positive coefficient of national saving which is significantly different from one for both gross and net values for the entire sample period. The study found capital formation in OECD countries is not financed by domestic saving only but a bigger portion is financed by external capital. This study 
acknowledges the effort by Feldstein et al (1980) in addressing the question of capital mobility in a globalized economy. It however notes that the authors used OECD data. As such, their findings cannot be generalized for non-OECD countries such as Kenya due to differences in saving behaviour.

Aghion, Comin, \& Howitt (2009) investigated the effect of domestic saving on productivity in 118 countries over the period 1960 to 2000 . Using a cross-country panel regression, the study found significant positive effect of lagged domestic saving on future growth in poor countries. However, the effect was statistically insignificant in rich countries. They also found that the effect does not work through capital formation channel but through total factor productivity (TFP) channel. This study observes that the cross-country study's results may not be generalized for non-sampled countries due to structural and institutional differences.

Ciftcioglu, \& Begovic (2010) tested the neoclassical hypothesis that higher savings lead to higher economic growth. Using data for 1995 to 2003, classical pooled regression results revealed that domestic saving had a positive and significant effect on economic growth of East and Central European countries over the sample period. To avert declines in investment due global crisis, the study recommended that policies that enhance total factor productivity and the rate of human capital formation be put into place. However, the bivariate approach does not captures the dynamics of a real economic setup. For instance, it does not bring out the link between domestic saving and capital formation.

Misztal (2011) studied the relationship between gross domestic saving (GDS) and GDP in advanced economies and emerging and developing countries over the period 1980 to 2010 . The study concluded that there is one-way long run causality between GDS and GDP in advanced economies, emerging and developing economies. This study appreciates the effort by Misztal (2011) by bringing to the fore the underlying relationship between domestic saving and economic growth across economies at different stages of development. However, like Ciftcioglu, \& Begovic (2010), the study does not address the question of the effect of domestic saving on economic growth via capital formation channel.

\subsection{Country-Specific Studies outside Africa's Context}

Narayan (2005) investigated the saving-investment nexus in China using data covering the fixed exchange regime (1952 to 1994) and fixed plus flexible exchange regime (1952 to 1998). The study found a statistically significant positive correlation between saving and investment in China over the two sample periods. The cointegrating test found the existence of long-run relationship between saving and investment. This study acknowledges the author's effort, especially in testing Feldstein \& Horioka (1980)'s puzzle for China's data, anon-OECD country. But like Feldstein \& Horioka (1980), Narayan's bivariate approach limits the application of the findings to a real economic situation where multiple macro variables jointly impact investment.

Bordoloi (2008) examined the relationship between gross domestic saving (GDS) and gross fixed capital formation (GFCF) in India over four phases in the evolution of India's economy over the period 1950 to 2006. The author specified a simple linear regression model with GFCF as the explained and GDS as the explanatory variable. Engle-Granger two-step analysis found evidence of long-run equilibrium relationship between GFCF and GDS in India with ECM correcting 50 per cent of deviations from long run equilibrium in one year. However, like Ciftcioglu, \& Begovic (2010), Bordoloi (2008) limited himself to bivariate analysis. Econometrically, failure to specify theoretically accepted variables into a model can lead to omitted variables bias and unreliable estimates. Seng (2014) studied the relationship between domestic saving and economic growth over the period 1989 to 2012. The author deployed the Granger causality test. The test results indicated that neither domestic saving Granger causes economic growth nor does economic growth Granger cause domestic saving. The study concluded that domestic saving and economic growth do dependent on each other in Cambodia. This study lauded Seng (2014) for adopting a country-specific analysis for Cambodian case. However, it failed to consider the link between capital formation and domestic saving despite the endorsement of the channel by the classical, neoclassical and new endogenous growth theories.

\subsection{Country-Specific Studies in Africa}

Akinola \& Omolade (2013) studied the relationship among gross national saving (GNS), gross capital formation (GCF) and GDP in Nigeria over a sample period of 1975 to 2008. The authors employed cointegration and VECM estimation techniques. The findings based on cointegration test indicated the presence of cointegrating relationship among GNS, GCF and GDP. Granger causality test showed that GDP has a bigger effect on GNS and GCF than the effect of GNS and GCF on GDP. The study concluded that there exist two-way causality among the study's variables. This study acknowledged the effort by Akinola \& Omolade (2013), especially their departure from earlier studies by using a larger sample size and trying to address the problem of endogeneity. But despite using a larger sample size and the VAR specification, this study failed to control for external sources of financing capital formation in Nigeria.

Elias \& Worku (2015) investigated the causal relationship between gross domestic saving and economic growth in Kenya, Uganda and Ethiopia over the period 1981-2014 using Johansen test for cointegration. The study 
found the existence of long-run relationship between domestic saving and growth in Uganda and Ethiopia but not in Kenya. The study recommended policies that the governments of Uganda and Ethiopia should implement policies that enhance domestic saving in order to realize sustainable growth. This study lauded the work of Elias \& Worku (2015) for adopting a comparative approach. However, like Seng (2014), it failed to consider the link between capital formation and domestic saving despite the commendation of the link by the classical, neoclassical and new endogenous growth theories.

Lucky \& Uzah (2016) investigated the effect of gross national savings (GNS/GDP) on gross fixed capital formation (GFCF) in Nigeria over the period 1981 to 2014. Cointegration test and VECM techniques were used. The findings reveal that GNS/GDP had negative but insignificant impact on GFCF. This study appreciates the authors' effort in subjecting Jhingan's propositions to empirical tests for validation. Though Lucky et al (2016) test Jhingan's proposition that domestic credit and external debt finance capital formation, they fail to control for the effect of multilateral aid, bilateral aid, FDI and diaspora remittance.

Shimelis (2016) investigated the causal relationship among domestic saving on domestic investment and economic growth in Ethiopia. The study employed data for the period 1969/70 to 2010/11. ARDL Bounds test found the existence of cointegrating relationship among gross domestic saving (GDS), gross domestic investment (GDI), GDP, labour and human capital formation (HCF) when GDP is specified as the target variable. ARDL estimation indicated that labour and GDI have positive significant impact on GDP in the short run and long run. GDS and HCF failed to achieve statistical significance. The results were robust for IRFs approach. The study recommended that the government of Ethiopia should increase saving and investment in order to achieve high and sustainable growth. This study applauds Shimelis (2016) for considering human capital variable in his multivariate causality framework. But the study's limitation to human capital fails to appreciate the neoclassical growth hypothesis which postulates positive relationship between physical capital formation and saving.

\subsection{Studies in Kenya}

Mwega, Mwangi \& Oleww-Ochilo (1994) investigated the effect of the saving gap, trade gap and fiscal gap on economic growth in Kenya. The purpose of the study was to establish whether it is the saving gap or trade gap or fiscal gap that constrains growth in Kenya. Data for the period 1967 to 1990 was used. After controlling for time trend, OLS estimation found the trade gap to be the binding constraint to growth in Kenya. This study appreciated the innovations by Mwega et al (1994) especially by extending the two-gap analysis. Though the findings represent a landmark development in macroeconomic analysis based on Kenya's experience, it remains unclear whether the binding constraint would be the same if the gaps were allowed to enter the growth equation via the capital formation channel.

Mbaluku (2011) investigated the effect of gross national savings (GNS) on gross fixed capital formation (GFCF) in Kenya over the period 1970 to 2009. The Granger causality test found a bidirectional relationship between inward FDI and GFCF with the impact of GFCF on FDI being stronger than the reverse. OLS estimates of linear regression equation found positive and significant effect of GNS on GFCF. Though the study controlled for FDI, it failed to capture the effect of foreign aid and other international private direct investments such as diaspora remittance.

\section{Methodology of the Study}

\subsection{Theoretical Model}

The Solow model (Solow, 1956) was used to underpin the study. The preference of the neoclassical growth model over others was motivated by its support for domestic saving as the source of growth via the capital formation channel. According to Solow model, physical capital formation evolves according to the following equation:

$\dot{k}=\frac{\partial \dot{K}}{\partial t}=s f\left(k_{t}\right)-(\mathrm{n}+\mathrm{g}+\delta) k_{t}$

Where $k$ refers to capital deepening; n refers to the growth rate of population; $g$ refers to the growth rate of technology; s refers to the saving rate; $\delta$ refers to the rate of depreciation; $s f\left(k_{t}\right)$ refers to saving per capita out of output per capita that is necessary to keep capital-labour ratio constant (steady-state); $(\mathrm{n}+\mathrm{g}+\delta) k_{t}$ refers to effective depreciation per capita. The inclusion of technology in the capital formation model was based on Solow's conclusion that in the long run it is not the investment in the machinery that will be the source of growth but technology change. It thus follows from equation (3.1) that given two countries that are identical in every respect except the rate of savings, then the higher rate of saving generates a higher rate of capital formation and a higher per capita capital in the long-run.

\subsection{Econometric Models}

3.2.1 Autoregressive Distributed Lag Model

To facilitate the estimation of long run effects of domestic saving on capital formation, this study specified an 
ARDL model following the traditions of Pesaran, Shin \& Smith $(1995,1999)$. The choice of the dynamic ARDL model over the static models was informed by the fact that there is always time lag between saving and capital formation due to intermediation hitches. To test the null hypothesis that domestic savings do not affect capital formation in Kenya, saving per capita out of output per capita $\left(s f\left(k_{t}\right)\right)$ in the basic model 3.1 was approximated by lagged gross domestic saving $\left(\mathrm{GDS}_{\mathrm{t}-1}\right)$. In tandem with the literature, the study allowed lagged multilateral aid $\left(\mathrm{MAID}_{\mathrm{t}-1}\right)$, bilateral aid $\left(\mathrm{BAID}_{\mathrm{t}}\right)$, foreign direct investment $\left(\mathrm{FDI}_{\mathrm{t}}\right)$, lagged diaspora remittance $\left(\mathrm{DR}_{\mathrm{t}-1}\right)$, lagged external debt $\left(\mathrm{ED}_{\mathrm{t}-1}\right)$, lagged openness to trade $\left(\mathrm{OPEN}_{\mathrm{t}-1}\right)$ to additively enter model 3.1 as control variables in order to minimize omitted variables bias. The study also controlled for monetary policy proxied by inflation (INF $\left.F_{t}\right)$. Lagging of the variables was aimed at minimizing multicollinearity in the data. In the tradition of Koyck (1954) and Almon (1965) distributed lag modelling procedure, lagged gross capital formation $\left(\mathrm{GCF}_{\mathrm{t}-1}\right)$ was introduced to account for inertia (own effect). Natural logarithmic transformation of the variables was aimed at enhancing the linearity of the model (Asteriou \& Price, 2007). It was also meant for improving normality and elimination of heteroskedasticity from the residuals. The constant term $\left(\pi_{0}\right)$ was included in order to account for the effect of the factors of capital formation that were beyond the study's knowledge. By assuming that the growth rate of population growth rate $(\mathrm{n})$, the growth rate of technology $(\mathrm{g})$ and the rate of depreciation $(\delta)$ have negligible effect on capital formation in Kenya; and by relaxing Solow's assumption of fixed saving rate in order to capture the recent dynamics in domestic saving in Kenya; and by broadening Solow's physical capital formation to include human capital formation as demonstrated by Mankiv, Romer \& Well (1992), the ARDL $\left(v, v_{1}, v_{2}, v_{3}, v_{4}, v_{5}, v_{6}\right.$, $\left.v_{7}, v_{8}\right)$ model was specified as follows:

$$
\begin{aligned}
& \text { LNGCF }_{\mathrm{t}}=\Omega_{0}+\sum_{\mathrm{i}=1}^{\mathrm{v}} \mathrm{x}_{1 \mathrm{i}} \text { LNGCF }_{\mathrm{t}-\mathrm{i}}+\sum_{\mathrm{i}=1}^{v_{1}} \mathrm{x}_{2 \mathrm{i}} \text { LNGDS }_{\mathrm{t}-\mathrm{i}}+\sum_{\mathrm{i}=1}^{v_{2}} x_{3 \mathrm{i}} \text { LNMAID }_{\mathrm{t}-\mathrm{i}}+\sum_{\mathrm{i}=0}^{v_{3}} \mathrm{x}_{4 \mathrm{i}} \text { LNBAID }_{\mathrm{t}-\mathrm{i}} \\
& +\sum_{\substack{\mathrm{i}=0 \\
v_{8}}}^{v_{4}} \mathrm{x}_{5 \mathrm{i}} \text { LNFDI }_{\mathrm{t}-\mathrm{i}}+\sum_{\mathrm{i}=1}^{v_{5}} \mathrm{x}_{6 \mathrm{i}} \text { LNDR }_{\mathrm{t}-\mathrm{i}}+\sum_{\mathrm{i}=1}^{v_{6}} \mathrm{x}_{7 \mathrm{i}} \text { LNED }_{\mathrm{t}-\mathrm{i}}+\sum_{\mathrm{i}=1}^{v_{7}} \mathrm{x}_{8 \mathrm{i}} \text { LNOPEN }_{\mathrm{t}-\mathrm{i}} \\
& +\sum_{\mathrm{i}=0}^{v_{8}} x_{9 \mathrm{i}} \mathrm{LNINF}_{\mathrm{t}-\mathrm{i}}+\varepsilon_{\mathrm{t}}
\end{aligned}
$$

Where $\Omega_{0}$ is the drift component; $\chi_{1 \mathrm{i}}, \chi_{2 \mathrm{i}}, \chi_{3 \mathrm{i}}, \chi_{4 \mathrm{i}}, \chi_{5 \mathrm{i}}, \chi_{6 \mathrm{i}}, \chi_{7 \mathrm{i}}, \chi_{8 \mathrm{i}}$ and $X_{9 \mathrm{i}}$ represented long run elasticities; $v$, $v_{1}, v_{2}, v_{3}, v_{4}, v_{5}, v_{6}, v_{7}$ and $v_{8}$ were lag lengths such that the random error $\varepsilon_{\mathrm{t}}$ was normally distributed, homoscedastic and serially uncorrelated with stable elasticities over time.

3.2.2 Error Correction Mechanism (ECM) Model

Since cointegrating relationship was found to exist among the study's variables, the ECM model was specified in to determine the speed of error correction. ECM model is a specification that expresses the first difference of the dependent variable as a function of first difference(s) of dependent variable(s), lagged error term and the white noise process. ECM model was specified as

$$
\begin{aligned}
& \Delta \mathrm{LNGCF}_{\mathrm{t}}=\sigma_{0}+\sum_{\mathrm{i}=1}^{\mathrm{p}} \theta_{1 \mathrm{i}} \Delta \mathrm{LNGCF}_{\mathrm{t}-\mathrm{i}}+\sum_{\mathrm{i}=1}^{p_{1}} \theta_{2 \mathrm{i}} \Delta \mathrm{LNGDS}_{\mathrm{t}-\mathrm{i}}+\sum_{\mathrm{i}=1}^{p_{2}} \theta_{3 \mathrm{i}} \Delta \text { LNMAID }_{\mathrm{t}-\mathrm{i}}+\sum_{\mathrm{i}=0}^{p_{3}} \Theta_{4 \mathrm{i}} \Delta \text { LNBAID }_{\mathrm{t}-\mathrm{i}} \\
& +\sum_{\mathrm{i}=1}^{p_{4}} \Theta_{5 \mathrm{i}} \Delta \mathrm{LNFDI}_{\mathrm{t}-\mathrm{i}}+\sum_{\mathrm{i}=1}^{p_{5}} \Theta_{6 \mathrm{i}} \Delta \mathrm{LNDR}_{\mathrm{t}-\mathrm{i}}+\sum_{\mathrm{i}=1}^{p_{6}} \Theta_{7 \mathrm{i}} \Delta \mathrm{LNED}_{\mathrm{t}-\mathrm{i}}+\sum_{\mathrm{i}=1}^{p_{7}} \Theta_{8 \mathrm{i}} \Delta \mathrm{LNOPEN}_{\mathrm{t}-\mathrm{i}} \\
& +\sum_{\mathrm{i}=1}^{p_{8}} \theta_{9 \mathrm{i}} \Delta \mathrm{LNINF}_{\mathrm{t}-\mathrm{i}}-\varkappa \mathrm{ECM}_{\mathrm{t}-1}+u_{\mathrm{t}}
\end{aligned}
$$

Where $\Delta$ denotes first difference operator; $\sigma_{0}$ denotes the drift component; $\theta_{1}, \theta_{2}, \theta_{3}, \theta_{4}, \theta_{5}, \theta_{6}, \theta_{7}, \theta_{8}$ an $\theta_{9}$ denote short-run elasticities; $p, p_{1}, p_{2}, p_{3}, p_{4}, p_{5}, p_{6}, p_{7}$ and $p_{8}$ represent lag lengths such that the random disturbance $u_{\mathrm{t}}$ is serial uncorrelated; $\mathrm{ECM}_{\mathrm{t}-\mathrm{i}}$ is the error correction term lagged one period; $\boldsymbol{x}$ measures the speed of short-run adjustment to long-run equilibrium following a shock to the system. The coefficient should take a value between -1 and 0 in order to avoid nonsensical correction speed. According to Granger (1988) representation theory, negative and significant error correction term is a necessary condition for the variables under investigation to be cointegrated.

3.2.3 Vector Auto-Regression (VAR) Model

To test the hypothesis that capital formation does not respond to shocks in domestic saving, vector auto-regression (VAR) model was specified in the tradition of Sims (1980). The impulse response functions (IRFs) were used to trace the impact of shocks to domestic saving on capital formation. For this study, a nine-variable VAR (1) model was specified in compact form as follows: 


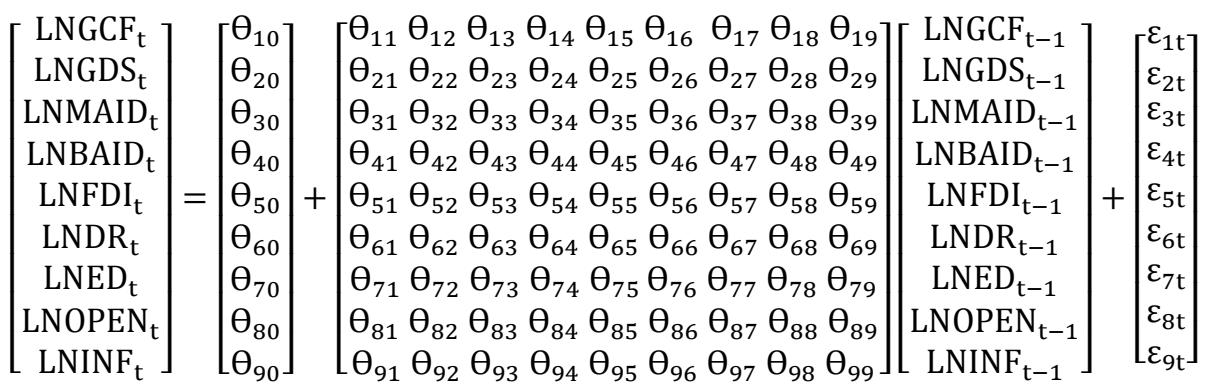

The vector autoregressive moving average (VARMA) representation of the above VAR is

\begin{tabular}{|c|c|c|c|c|c|c|c|}
\hline$\left[\mathrm{LNGCF}_{\mathrm{t}}\right]$ & & LNGCF & & & & & $\varepsilon \mathrm{LNGCF}_{\mathrm{t}-1}$ \\
\hline LNGDS $_{\mathrm{t}}$ & & $\overline{\text { LNGDS }}$ & & & & & $\varepsilon \mathrm{LNGDS}_{\mathrm{t}-1}$ \\
\hline LNMAID $_{t}$ & & LNMAID & & & & & $\varepsilon^{2} \mathrm{LMAID}_{\mathrm{t}-1}$ \\
\hline $\mathrm{LNBAID}_{\mathrm{t}}$ & & $\overline{\text { LNBAID }}$ & $\stackrel{\theta_{11}(\mathrm{i})}{-}$ & & $\theta_{19}(\mathrm{i})$ & & $\varepsilon \mathrm{LNBAID}_{\mathrm{t}-1}$ \\
\hline $\mathrm{LNFDI}_{\mathrm{t}}$ & $=$ & LNFDI & $+>$ & $\because$ & & + & $\varepsilon \mathrm{LNFDI}_{\mathrm{t}-1}$ \\
\hline $\mathrm{LNDR}_{\mathrm{t}}$ & & LNDR & $\overbrace{i=1}\left[\theta_{91}(\mathrm{i})\right.$ & $\cdots$ & $\theta_{99}(\mathrm{i})$ & & $\varepsilon \mathrm{LNDR}_{\mathrm{t}-1}$ \\
\hline $\mathrm{LNED}_{\mathrm{t}}$ & & LNED & & & & & $\varepsilon \mathrm{LNED}_{\mathrm{t}-1}$ \\
\hline LNOPEN $_{\mathrm{t}}$ & & LNOPEN & & & & & $\varepsilon \mathrm{LNOPEN}_{\mathrm{t}-1}$ \\
\hline $\mathrm{LNINF}_{\mathrm{t}}$ & & LNINF & & & & & $\varepsilon$ ININ \\
\hline
\end{tabular}

More compactly, the condensed VARMA is given as

$$
\Delta \mathrm{X}_{\mathrm{t}}=\sum_{\mathrm{j}=0}^{\infty} \theta_{\mathrm{i}} \varepsilon_{\mathrm{t}-\mathrm{i}} \quad \mathrm{i}=1,2, \ldots \ldots \ldots, \mathrm{n}
$$

Where $\theta_{i}$ is the impact multiplier denoting the response of each variable to innovations in each of the corresponding error terms on impact; $\varepsilon_{t-i}$ are innovations; $n$ is the number of variables in the system; $\theta_{i}(0)$, $\theta_{\mathrm{i}}(1), \theta_{\mathrm{i}}(\mathrm{n})$ are the impulse responses plotted to trace the time path of the system variables as they respond to various shocks over time.

\subsection{Estimation Procedure and Techniques}

\subsubsection{Pre-Estimation Procedures}

This study conducted a correlation analysis in order to determine the magnitude and the direction of the correlationship among the variables. Determining the magnitude of correlationship was useful in establishing the degree of multicollinearity in the data. This was important given that under exact collinearity, the regressors' matrix does not have full column rank. This situation could lead to indeterminate coefficient estimates or infinitely large standard errors and small t-values even when the goodness of fit of the model was high.

Unit root tests were conducted in order to determine whether the time series were stationary or non-stationary. Stationarity or non-stationarity of a series determines its behaviour. For example, a shock to the series does not die with non-stationarity but with stationarity. It implies that the application of non-stationary time series data to analysis could produce spurious test statistics because of non-constant means and variances (Granger \& Paul, 1974). Although ARDL estimation technique does not require pre-testing for unit roots, to ensure that ARDL model did not collapse in the presence of integrated series of I(2), Augmented Dickey-Fuller (ADF) was used to test for unit roots because of the parametric nature of the data.

This study selected a maximum lag of 2 according to the recommendation by Pesaran \& Shin (1999) for annual data. The choice of an appropriate lag length is important in the estimation of the ARDL model since the use of long lags lead to over-parametisation, serially correlated errors and unstable slopes/elasticities. The optimum lag for each variable was determined through an automatic selection criteria using Akaike information criteria (AIC) since the study's sample size was less than 60. According to Khim-Sen \& Tai-leung Chong (2005) for sample sizes of 60 and below, AIC selects optimal lengths without prejudicing parsimony. Unlike the fixed selection criteria which imposes untested restriction to the model before estimation, the automatic selection generates information about the model's lag structure from the data itself during estimation once the maximum lag is picked. According to Nwachukwu \& Egwaikhide (2007), fixing the lag structure before estimation is the main cause of misspecification and wrong forecasts.

3.3.2 Estimation Procedures

The study implemented the ARDL procedure in two steps in the tradition of Pesaran \& Pesaran (1997). The first step involved testing of the null hypotheses of no cointegrating relationship. This study employed bounds testing approach to level relationship developed by Pesaran \& Shin (2001). The preference of the ARDL bounds testing approach over the traditional cointegration testing procedures was informed by the fact that unlike the traditional approaches which require that series be integrated at the same order, Pesaran, Shin \& Smith (2001) bounds test 
can be applied to series that are not integrated at the same order, provided the order does not exceed two. The choice was also informed by the fact that Pesaran, Shin \& Smith (2001) bounds test procedure does not require reparametisation of the model into corresponding VEC model. This makes it easier for one to interpret the results. The study used level elasticities in the CEC model to test the null hypotheses of no cointegration. The calculated F-statistic from Wald test for cointegration were compared to two asymptotic critical values corresponding to polar cases of all variables being purely $\mathrm{I}(0)$ or purely I(1). The conclusions about the test results were based on thresholds provided by Narayan (2004). The study preferred Narayan's thresholds over those provided by Pesaran \& Shin (2001) due their suitability for small samples (Boakye, 2008).

The second step in the estimation process involved the estimation of long run elasticities and short run elasticities in model 3.2 and 3.3 respectively. This study employed the ARDL method developed by Pesaran \& Shin $(1995,1999)$ and Pesaran \& Pesaran (1996) to estimate the ARDL model. The study's preference of ARDL method over the traditional OLS was informed by the fact that it produces accurate long run estimates and t-values even in the presence of endogeneity (Ojiambo, 2013).

3.3.3 Post-Estimation Procedures

To guarantee validity and reliability of the estimates, this study conducted one data and a battery of six residual diagnostic tests. The data test involved the Ramsey's RESET of functional form. Residual tests included serial correlation test (Breusch-Godfrey LM Test), heteroskedasticity test (Breusch-Pagan-Godfrey test), normality test (Jarque-Bera, histogram plus superimposed normal distribution density curve for residuals) and stability tests (CUSUM tests, CUSUM square tests and recursive coefficient tests).

\section{Results, Interpretation and Discussion}

4.1 Correlation Analysis

Table 2: Correlation Matrix of OLS Correlation Analysis

\begin{tabular}{|c|c|c|c|c|c|c|c|c|c|}
\hline & GCF & GDS & MAID & BAID & FDI & DR & ED & OPEN & INF \\
\hline \multirow[t]{3}{*}{ GCF } & {$[1.000]$} & & & & & & & & \\
\hline & ----- & & & & & & & & \\
\hline & ----- & & & & & & & & \\
\hline \multirow[t]{3}{*}{ GDS } & {$[0.916]$} & {$[1.000]$} & & & & & & & \\
\hline & (14.78) & ---- & & & & & & & \\
\hline & $\{0.000\}$ & ----- & & & & & & & \\
\hline \multirow[t]{3}{*}{ MAID } & [0.953] & [0.847] & {$[1.000]$} & & & & & & \\
\hline & (20.45) & (10.31) & ----- & & & & & & \\
\hline & $\{0.000\}$ & $\{0.000\}$ & ----- & & & & & & \\
\hline \multirow[t]{3}{*}{ BAID } & {$[0.672]$} & {$[0.554]$} & {$[0.761]$} & [1.000] & & & & & \\
\hline & $(5.876)$ & $(4.317)$ & $(7.597)$ & ----- & & & & & \\
\hline & $\{0.000\}$ & $\{0.001\}$ & $\{0.000\}$ & ----- & & & & & \\
\hline \multirow[t]{3}{*}{ FDI } & {$[0.774]$} & {$[0.659]$} & {$[0.751]$} & {$[0.511]$} & {$[1.000]$} & & & & \\
\hline & (7.931) & 5.678 & $(7.364)$ & (3.851) & ---- & & & & \\
\hline & $\{0.000\}$ & $\{0.001\}$ & $\{0.000\}$ & $\{0.000\}$ & ----- & & & & \\
\hline \multirow[t]{3}{*}{ DR } & [0.956] & [0.857] & {$[0.920]$} & [0.659] & {$[0.721]$} & {$[1.000]$} & & & \\
\hline & (21.03) & (10.78) & (15.26) & (5.678) & $(6.749)$ & ----- & & & \\
\hline & $\{0.000\}$ & $\{0.000\}$ & $\{0.000\}$ & $\{0.000\}$ & $\{0.000\}$ & ----- & & & \\
\hline \multirow[t]{3}{*}{ ED } & [0.895] & {$[0.825]$} & {$[0.847]$} & [0.639] & {$[0.597]$} & [0.923] & [1.000] & & \\
\hline & (13.01) & (9.465) & (10.33) & (5.377) & $(4.820)$ & $(15.820)$ & ----- & & \\
\hline & $\{0.000\}$ & $\{0.000\}$ & $\{0.000\}$ & $\{0.000\}$ & $\{0.000\}$ & $\{0.000\}$ & ----- & & \\
\hline \multirow[t]{3}{*}{ OPEN } & [0.843] & {$[0.700]$} & [0.938] & {$[0.720]$} & [0.652] & [0.856] & {$[0.800]$} & {$[1.000]$} & \\
\hline & (10.16) & $(6.340)$ & $(17.570)$ & (6.763) & (5.567) & $(10.722)$ & (8.653) & ----- & \\
\hline & $\{0.000\}$ & $\{0.000\}$ & $\{0.000\}$ & $\{0.000\}$ & $\{0.000\}$ & $\{0.000\}$ & $\{0.000\}$ & ----- & \\
\hline \multirow[t]{3}{*}{ INF } & {$[-0.293]$} & {$[-1.163]$} & {$[-0.298]$} & {$[-0.216]$} & {$[-0.179]$} & {$[-0.277]$} & {$[-0.217]$} & {$[-0.334]$} & {$[1.000]$} \\
\hline & $(-1.986)$ & $(-1.072)$ & $(-2.021)$ & $(-1.431)$ & $(-1.177)$ & $(-1.871)$ & $(-1.444)$ & $(-2.300)$ & ---- \\
\hline & $\{0.054\}$ & $\{0.290\}$ & $\{0.050\}$ & $\{0.160\}$ & $\{0.246\}$ & $\{0.068\}$ & $\{0.156\}$ & $\{0.027\}$ & ----- \\
\hline
\end{tabular}

KEY: Correlation coefficients are presented in square brackets []; t-statistics are presented in parentheses ( ); the probabilities of the t-statistics are presented in curly brackets $\{\hat{\}}$.

Table 2 represents a correlation matrix of OLS estimated results for 44 observations over a period 1974 to 2017. The results demonstrate that there is high multicollinearity in the study's data. According to Gujarati (2005), multicollinearity is severe if the correlation coefficient exceeds 0.8 . The strong correlations among gross capital 
formation and the financial variables was expected because theoretically, domestic saving, multilateral aid, bilateral aid, foreign direct investment, diaspora remittance and trade are supposed to be the sources of financing capital formation. The potential problem of high multicollinearity was circumvented by logarithmic transformation of the data and lagging.

\subsection{Unit Test Analysis}

Table 3: Results of Augmented Dickey-Fuller (ADF) Unit Root Tests

\begin{tabular}{|l|l|l|l|}
\hline & ADF Test Statistic (Intercept and Trend) & \\
\hline Variable & Level & Fist Difference & Order of Integration \\
\hline LnGCF & -1.628 & $-6.234 * * *$ & $\mathrm{I}(1)$ \\
\hline LnLGCF & -1.697 & $-6.3762 * * *$ & $\mathrm{I}(1)$ \\
\hline LnGDS & -1.423 & $-6.0328 * * *$ & $\mathrm{I}(1)$ \\
\hline LnMAID & -0.6870 & $-10.61 * * *$ & $\mathrm{I}(1)$ \\
\hline LnBAID & $-4.677 * * *$ & $-6.515^{* * *}$ & $\mathrm{I}(0)$ \\
\hline LnFDI & $-4.985^{* * *}$ & $-7.725 * * *$ & $\mathrm{I}(0)$ \\
\hline LnDR & $-4.460 * * *$ & $-6.092^{* * *}$ & $\mathrm{I}(0)$ \\
\hline LnED & -1.740 & $-4.104 * *$ & $\mathrm{I}(1)$ \\
\hline LnOPEN & -1.147 & $-6.455^{* * *}$ & $\mathrm{I}(1)$ \\
\hline LnINF & $-5.258 * * *$ & $-7.859 * * *$ & $\mathrm{I}(0)$ \\
\hline \multicolumn{5}{|l}{} \\
\hline MacKinnon Critical Values for the Rejection of Unit Root & First Difference \\
\hline & Level & -4.199 \\
\hline $1 \%$ level & -4.192 & -3.524 \\
\hline $5 \%$ level & -3.521 & -3.193 \\
\hline $10 \%$ level & -3.191 & \\
\hline
\end{tabular}

Note: $* * *$ means the ADF statistic was significant at $1 \%$ level of significance. ${ }^{*}$ means the ADF statistic was significant at 5\% level of significance. * means the ADF statistic was significant at $10 \%$ level of significance.

Table 3 shows ADF test statistics for natural log transformed series and the MacKinnon critical values for the rejection/acceptance of the null hypotheses that the series have unit roots. The results indicate that Augmented Dickey-Fuller (ADF) test accepted the null hypothesis of unit root for LnGCF, LnLGCF, LnGDS, LnMAID, LnBAID, LnFDI, LnDR LnED, LnOPEN and LnINF at 5 per cent level of significance after first differencing. The demonstration by ADF unit root tests that some of the series follow a random walk justified the study's preference for Pesaran, Shin \& Smith (2001) ARDL bounds testing procedure over the traditional cointegration testing procedures. That is, ARDL bounds test procedure meets the condition that the dependent variable for the model should be integrated of order I(1), while the explanatory variables can be $\mathrm{I}(0)$ or $\mathrm{I}(1)$ but not $\mathrm{I}(2)$ for the specified model.

4.3 Cointegration Analysis

Table 4: Bounds Test for Cointegration

\begin{tabular}{|lllll|}
\hline F-Bounds Test & \multicolumn{4}{l}{ Null Hypothesis: No levels relationship } \\
\hline \hline Test Statistic & Value & Significance & I $(0)$ & I $(1)$ \\
\hline \hline F-statistic & \multirow{2}{*}{3.464} & $10 \%$ & 1.85 & 2.85 \\
K & 8 & $5 \%$ & 2.11 & 3.15 \\
& & $2.5 \%$ & 2.33 & 3.42 \\
& & $1 \%$ & 2.62 & 3.77 \\
\hline \hline
\end{tabular}

Table 4 results indicate that the calculated F-statistic of 3.464 exceeds the I(1) upper bound critical value of 3.15 provided by Narayan (2004) at 5 per cent level of significance. Consequently, the study rejected the null hypothesis that all elasticities for long relationship are equal to zero. The study preferred Narayan's thresholds over those provided by Pesaran \& Shin (2001) due their suitability for small samples as advised by (Boakye, 2008). The results paved the way for the estimation of long run relationship equation and the speed of adjustment back to long run equilibrium in the event of shocks to the system. 


\subsection{Diagnostic Tests}

Table 5: Results of diagnostic tests for ARDL(2, $0,0,2,2,1,2,1,0)$ model

\begin{tabular}{|l|c|c|}
\hline Test Stat & F Version & $\chi^{2}$ Version \\
\hline Functional Form* & $\mathrm{F}[1,21]=1.0544(0.316)$ & Not Applicable \\
\hline Serial Correlation** & $\mathrm{F}[2,20]=0.5564(0.582)$ & $\mathrm{CHSQ}[2]=2.161(0.340)$ \\
\hline Heteroskedasticity*** & $\mathrm{F}[18,20]=0.8679(0.616)$ & $\mathrm{CHSQ}[18]=17.02(0.521)$ \\
\hline Normality**** & Not Applicable & CHSQ[2] $=1.355(0.508)$ \\
\hline
\end{tabular}

Note: p-values in parentheses; *Ramsey's RESET test using the square of fitted values; ** Breusch-Godfrey Serial Correlation Lagrange Multiplier serial correlation test; *** Breusch-Pagan-Godfrey heteroskedasticity test based on the regression of squared residuals on squared fitted values; **** Jarque-Bera statistic based on skewness and kurtosis of residuals test.

Table 5 shows results of Breusch-Godfrey Serial Correlation LM Test for the violation of the classical linear regression model (CLRM) assumption of no serial correlation in the residuals. The probability for F-statistics for functional form, serial correlation and heteroskedasticity were all more than the p-value of 0.05. Similarly, the probability for Chi-Square statistics were all more than the p-value of 0.05 . The probability for the Jarque-Bera statistic was also found to be more than the p-value of 0.05 . The study concluded that the ARDL $(2,0,0,2,2,1,2$, $1,0)$ model was correctly specified and that its residuals were normally distributed and free from serial correlation and heteroskedasticity.

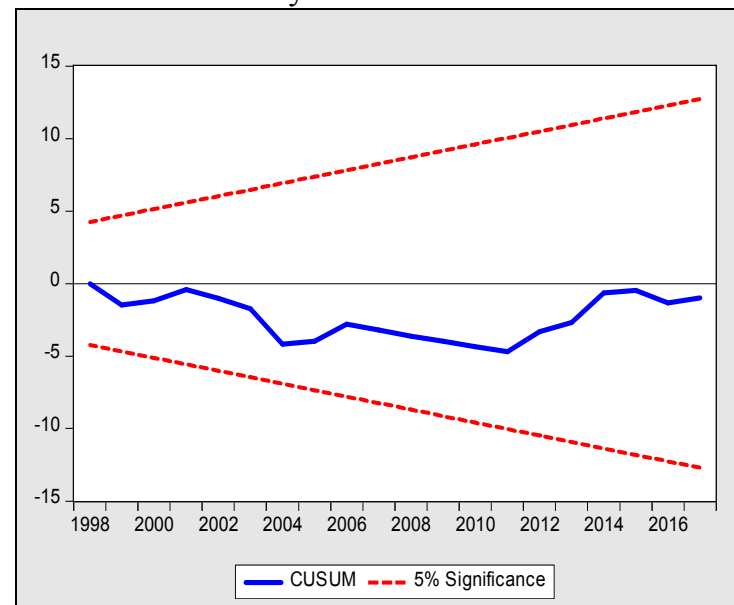

Figure 1: Recursive Residuals CUSUM

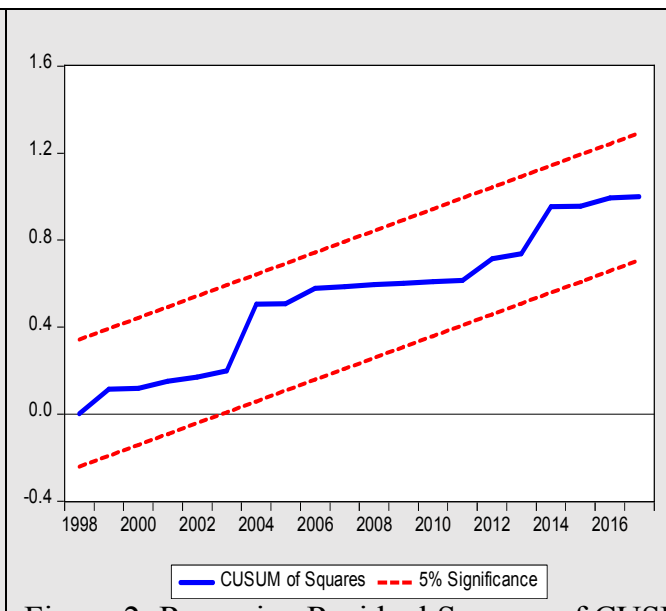

Figure 2: Recursive Residual Squares of CUSUM

Figure 1 shows that the cumulative sum (CUSUM) of residuals for ARDL model are within 5 per cent critical lines. Similarly, figure 2 shows that the cumulative sum of squares (CUSUMSQ) of residuals for ARDL model are within 5 per cent critical lines. According to Brown, Durbin, \& Evans (1975), if the CUSUM and CUSUMSQ remain within the region defined by the 5 per cent bound lines, then the study should conclude that there is parameter stability. Based on the CUSUM and CUSUMSQ charts therefore, the study concluded that the parameters for $\operatorname{ARDL}(2,0,0,2,2,1,2,1,0)$ model were stable. This study cautioned researchers against relying on CUSUM test only since it can indicate that parameters are stable even if the residuals are serially correlated. According to Shrestha \& Chowdhury (2005), CUSUSQ is the best test for the appropriateness of the selected lag length.

\subsection{Long Run and Short Run Dynamics}

The successful diagnostic tests in 4.4 implied that the estimates are valid and therefore reliable. This paved the way for the presentation of the estimates of ARDL model and ECM model for interpretation and discussion. The results for ARDL model are presented in table 6 while those for ECM model are presented in table 7. 
Table 6: Estimated Long Run Elasticities of Capital Formation Model

\begin{tabular}{|c|c|c|c|}
\hline Variable & Elasticity & t-Stat. & Prob. \\
\hline $\operatorname{lnGCF}(-1)$ & 0.2744 & 1.3815 & 0.1810 \\
\hline $\ln G C F(-2)$ & 0.3300 & 1.8969 & 0.0710 \\
\hline $\operatorname{lnGDS}$ & 0.4235 & 3.1553 & 0.0046 \\
\hline $\operatorname{lnMAID}$ & 0.0100 & 0.0776 & 0.9389 \\
\hline $\operatorname{lnBAID}$ & 0.1009 & 1.2550 & 0.2227 \\
\hline $\operatorname{lnBAID}(-1)$ & -0.1628 & -2.1049 & 0.0469 \\
\hline $\ln \mathrm{BAID}(-2)$ & 0.0910 & 1.4618 & 0.1579 \\
\hline $\operatorname{lnFDI}$ & -0.0065 & -0.2454 & 0.8084 \\
\hline $\operatorname{lnFDI}(-1)$ & 0.0488 & 1.4848 & 0.1518 \\
\hline $\operatorname{lnFDI}(-2)$ & -0.0675 & -1.9768 & 0.0607 \\
\hline $\operatorname{lnDR}$ & 0.1254 & 1.7722 & 0.0902 \\
\hline $\operatorname{lnDR}(-1)$ & -0.1505 & -2.2121 & 0.0376 \\
\hline $\operatorname{lnED}$ & -0.4115 & -0.9360 & 0.3594 \\
\hline $\operatorname{lnED}(-1)$ & 1.1561 & 1.7717 & 0.0903 \\
\hline $\ln \mathrm{ED}(-2)$ & -1.2196 & -2.3084 & 0.0308 \\
\hline $\operatorname{lnOPEN}$ & -0.1095 & -0.3135 & 0.7568 \\
\hline $\operatorname{lnOPEN(-1)}$ & 0.5054 & 1.7693 & 0.0907 \\
\hline $\operatorname{lnINF}$ & -0.1443 & -2.6089 & 0.0160 \\
\hline $\mathrm{C}$ & 9.4157 & 3.1301 & 0.0049 \\
\hline R-squared & 0.9793 & & \\
\hline Adjusted R-squared & 0.9623 & & \\
\hline F-statistic & 57.727 & & \\
\hline Prob(F-statistic) & 0.0000 & & \\
\hline
\end{tabular}

The results in table 6 show that 97.93 per cent of the variations in gross capital formation are explained by the model's explanatory variables before adjusting for the degrees of freedom. Only 2.07 per cent of the variation in gross capital formation are not explained. Since majority of the variations in gross capital formation are explained, the study concluded that the long run model fits data observations well. This decision was cemented by the F-test's rejection of the null hypothesis that all elasticities for long run relationship are zero.

The study's null hypothesis was that domestic saving does not affect capital formation in Kenya. Table 6 reveals that in the long run, at 5 per cent level of significance, the elasticity of domestic saving is statistically significant. The positive sign for the elasticity is in tandem with a priori expectation. The elasticity of 0.4235 implies that a 10 per cent increase in gross domestic saving leads to 4.235 per cent increase in gross capital formation in the long run other factors remaining constant. In other words, US \$1 increase in gross domestic saving leads to US\$ 0.562 increase in gross capital formation in the long run other factors remaining constant. As such, the study rejected the null hypothesis and concluded that domestic saving enhances capital formation in Kenya. The conclusion implies that Kenya's experience supports the classical, neoclassical and new endogenous growth theories which hypothesize that a rise in saving should lead to an increase in capital formation other condition remaining the same. The findings are in agreement with those of Mbaluku (2011) for Kenya over the period 1970 to 2009 .

However, Table 6 results indicate that the elasticities of inflation (LnINF) and the second lag of external debt (LnED) were negative and significant. It implies that in the long run, Kenya's capital formation is undermined by inflation and external borrowing. 
Table 7: Error Correction Representation for the Capital Formation Model

\begin{tabular}{|lrrr|}
\hline \hline Variable & Elasticity & t-Stat. & Prob. \\
\hline \hline & & & \\
$\Delta(\operatorname{lnGCF}(-1))$ & -0.3300 & -2.6034 & 0.0162 \\
$\Delta(\operatorname{lnBAID})$ & 0.1009 & 2.2050 & 0.0382 \\
$\Delta(\ln$ BAID $(-1))$ & -0.0910 & -2.2821 & 0.0325 \\
$\Delta(\operatorname{lnFDI})$ & -0.0065 & -0.4207 & 0.6781 \\
$\Delta(\operatorname{lnFDI}(-1))$ & 0.0675 & 4.0320 & 0.0006 \\
$\Delta(\operatorname{lnDR})$ & 0.1254 & 2.9094 & 0.0081 \\
$\Delta(\operatorname{lnED})$ & -0.4115 & -1.4536 & 0.1602 \\
$\Delta(\operatorname{lnED}(-1))$ & 1.2196 & 4.4508 & 0.0002 \\
$\Delta(\operatorname{lnOPEN})$ & -0.1095 & -0.6488 & 0.5232 \\
ECM(-1) & -0.3956 & -6.9867 & 0.0000 \\
\hline \hline R-squared & 0.6441 & & \\
Adjusted R-squared & 0.5408 & & \\
\hline \hline
\end{tabular}

Table 7 results indicate that the error correction term was statistically significant at 5 per cent level of significance. Its coefficient $(-0.3956)$ had the theoretically appropriate (negative) sign. It suggests that 39.56 per cent of deviations from long run equilibrium due to some shocks to the system are corrected in one year. The results support Engle-Granger (1987) representation theory. According to Engle-Granger (1987) representation theory, negative and significant error correction term signifies long run causality running from explanatory variables to the explained variable. The results support the ARDL bounds test findings that there is long run cointegrating relationship between gross capital formation and gross domestic saving and control variables. The results also indicate that domestic saving does not directly enter the short run model, rather it enters via the ECM term. Thus, in the short run, capital formation in Kenya is driven by external debt, bilateral aid during the program year, FDI and diaspora remittance as demonstrated by positive and statistically significant changes in their elasticities. Capital formation growth will however be undermined by lagged bilateral aid and capital formational inertia. The results indicate that it is not yet time for Kenya to declare to the West that it no longer needs her financial support.

4.6 Impulse Response Function Analysis

The second hypothesis of the study was that capital formation does not respond to shocks in domestic saving in Kenya. To test this hypothesis, the study generated the response to Cholesky one standard deviation innovations.

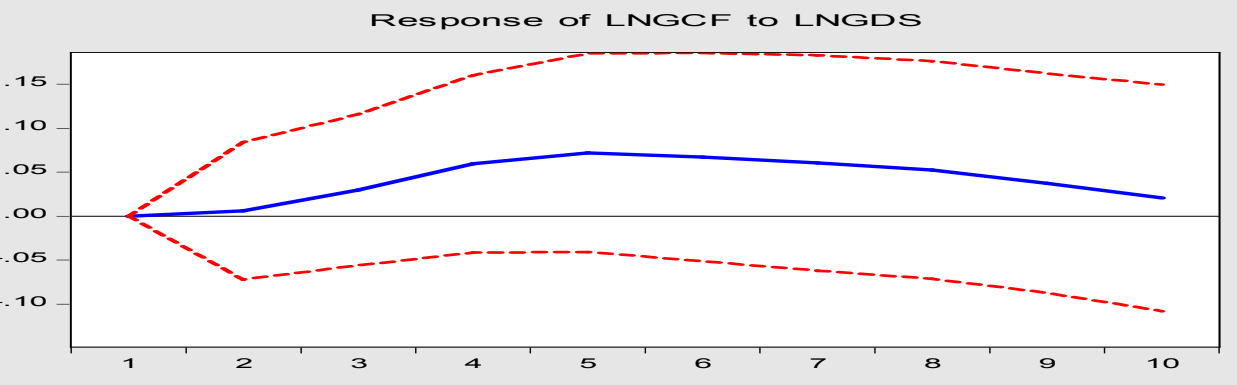

Figure 3: Response of capital formation to shocks in domestic saving

Figure 3 shows that the impact of one standard deviation innovation in gross domestic saving on gross capital formation rises gradually from zero to reach the peak in the positive territory after four and a half years. It then gradually declines to near zero by the end of the tenth year. Since the peak of the impulse response curve is above the 0.05 significance line, the study rejected the null hypothesis and concluded that capital formation responds significantly to innovations in domestic saving. The good news for the government of Kenya is that the response does not switch to the negative region. It implies that the shocks in domestic saving are favorable for capital formation in Kenya. The impulse response function analysis results suggest that there is a strong Granger causality running from gross domestic saving to gross capital formation. The results reinforce the ARDL generated ones in sub-section 4.5. 


\section{Conclusion}

The purpose of this study was to investigate the effect of domestic saving and the response of capital formation to shocks in domestic saving. The study found that domestic saving enhances capital formation in Kenya in the long run but inflation and lagged external debt retard it. However, in the short run, capital formation is not driven by domestic saving but by lagged external debt, current year bilateral aid, foreign direct investment and diaspora remittance while bilateral aid and capital formation inertia undermine it. Thus, Kenya's experience supports the classical, neoclassical and new endogenous growth theories which hypothesize that a rise in domestic saving should lead to an increase in capital formation in the long run other condition remaining the same. The results were robust for IRFs approach where the response of capital formation to innovations in domestic saving was positive and significant. Consequently, the study recommended that in order to enhance capital formation in Kenya in the long run, factors which promote domestic saving such as public saving, gross domestic product per capita, growth rate of gross domestic product per capita, terms of trade and the contribution of the industry to gross domestic product should be promoted. The study also recommended that factors that retard domestic saving such as dependency ratio, credit to gross domestic product ratio, rate of urbanization, bank density and real wealth should be checked.

\section{References}

Aghion, P., Comin, D., \& Howitt, P. (2009). When Does Domestic saving Matter? Accessed on July 31, 2019 from https://scholar.harvard.edu/files/aghion/files/when_does_domestic_saving_matter.pdf.

Akinola, G. W., \& Omolade, A. (2013). Saving, Gross Capital Formation and Economic Growth Nexus in Nigeria (175-2008). IOSR Journal of Economics and Finance, 1(2), 19-25. Accessed on Augast 1, 2019 from http://www.iosrjournals.org/iosr-jef/papers/vol1-issue2/D0121925.pdf?id=6408.

Almon, S. (1965). The Distributed Lag Between Capital Appropriation and Expenditures. Econometrica, 33(1), $178-196$

Asteriou, D., \& Price, S. (2007). Applied Econometrics: A Modern Approach. Basingstoke: Palgrave Macmillan.

Boakye, P. F. (2008). Foreign Aid and Economic Growth in Ghana (1970-2005). Unpublished Masters Dissertation, University of Science and Technology, Kumasi, Ghana.

Bordoloi, S. (2008). Saving and Capital Formstion in India: Some Exploration. Journal of Income and Wealth, $30(1)$.

Ciftcioglu, S., \& Begovi, N. (2010). Are domestic savings and economic growth correlated? Evidence from a sample of Central and East European countries. Problems and Perspectives in Management, 8(3), accessed $\begin{array}{llll}\text { on July } & 31, & 2019\end{array}$ fromhttps://businessperspectives.org/images/pdf/applications/publishing/templates/article/assets/3376/PPM EN_2010_03_Ciftciglu.pdf.

Elias, S., \& Worku, A. (2015). Causal relationship between Gross Domestic Saving and Economic Growth in East Africa: Evidence from Ethiopia, Uganda and Kenya. Journal of Agriculture and Social Research, 15(12), 31-39.

Engle, R. F., \& Granger, C. W. (1987). Cointegration and error correction: Representation, estimation and testing. Econometrica, 55, 251-276.

Feldstein, M., \& Horioka, C. (1980). Domestic Saving and International Capital Flow.The Economic Journal, 90(358), 314-329.

Geiger, L. T. (1990). Debt and Economic Development in Latin America. Journal of Economic Areas, 24, 181-194.

Granger, C. W., \& Paul, N. (1974). Spurious Regresssions in Econometrics. Journal of Econometrics, 2(2), 111 120.

Gujarati, D. (2005). Basic Econometrics. New York: Mc-Graw Hill.

Khim-Sen, V. L., \& Tai-leung Chong, T. (2005). Autoregressive Lag Length Selection Criteria in the Presence of ARCH Errors. Economic Bulletin, 3(19), 1-5.

Koyck, L. M. (1954). Distributed Lags and Investment Analysis. Amsterm: North-Holland.

Krugman, P. R. (1994, November/December). The Myth of Asia's Miracle. Froeign Affairs.

Kuznets, S. (1955). International Differences in Capital Formation and Financing. In U.-N. Bureau, Capital Formation and Economic Growth (pp. 17-110). Princeton: Princeton University Press.

Lewis, W. A. (1954, May 22). Economic Development with Unlimited Supplies of Labor. Manchester School of Economics \& Social Studies, 139-192.

Lucas, R. E. (1988). On the Mechanics of Economic Development . Journal of Monetary Economics, 22 , 3-42.

Lucky, A. L. (2016). Determinants of Capital Formation Nigeria: A Test of Jhinga's Propositions 1981-2014. ILARD International Journal of Bankng and Finance Research , 2(1).

Mankiv, N. G., Romer, D., \& Weil, D. N. (1992). A Contribution to the Empirics of Economic Growth. Quarterly 
Journal of Economics, 107, 407-437.

Mbaluku, G. N. (2011). The Impact of Foreign Direct Investment on Domestic Capital Formation: An Empirical Investigation for Kenya: 1970-2009. Nairobi: Accessed on February 19, 2018 from http://erepository.uonbi.ac.ke/bitstream/handle/11295/3241/Mbaluku_The\%20Impact\%20Of\%20Foreign\% 20Direct\%20Investment $\% 20$ On $\% 20$ Domestic $\% 20$ Capital $\% 20$ Formation $\% 20 \% 20 \mathrm{An} \% 20$ Empirical $\% 20$ Inv estigation $\% 20$ For $\% 20$ Kenya $\% 2$ C $\% 201970 \% 20200$.

Misztal, P. (2011). The relationship between Savings and Economic Growth in Countries with Different Levels of Economiv Development. Accessed on July $31, \quad 2019$ from http://cejsh.icm.edu.pl/cejsh/element/bwmeta1.element.0eb75c01-cd41-3c1d-8702 7895c731db8d/c/181.pdf.

Mwega, F. M., Mwangi, N., \& Olewe-Ochilo, F. (1994). Macroeconomic constraints and medium-term growth in Kenya: a three-gap analysis. African Economic Research Consortium, Accessed on August 26, 2019 from https://aercafrica.org/wp-content/uploads/2018/07/RP23.pdf.

Narayan, P. K. (2004). Reformulating the Critical Values for the Bounds R Statistics Approach to Cointegration: An Application to the Tourism Demand Model for Fiji. Discussion Papers, Department of Economics, Monash University, Australia.

Narayan, P. K. (2005). The Saving and Investment Nexus for China: Evidence from Cointegration Tests. Applied Economics, 37(17), 1979-1990.

Nurkse, R. (1953). Problems of Capital Formation in Underdeveloped Countries. The Economic Journal, 63(252), 897-899.

Nwachukwu, T. E., \& Egwaikhide, F. O. (2007). An Error-Correction Model of the Determinants of Private Saving in Nigeria. A Paper Presented at the African Economic Society (AES) Conference, Cape Town, South Africa, July 2007, Accessed from on July 13, 2019 from https://pdfs.semanticscholar.org/beef/32048f8bd38dd49d6dfbb428cd3eede9443b.pdf?_ga=2.90892825.206 9632426.1562984942-670911468.1553117748.

Ojiambo, E. V. (2013). Effect of Foreign Aid Predicability on Investment and Economic Growth in Kenya.

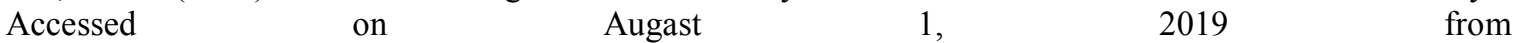
https://pdfs.semanticscholar.org/88a5/a6b7cd46f1d11ee007148d770def8b6cdd20.pdf.

Pesaran H, M., \& Pesaran, B. (1997). Microfit 4.0. Oxford: Oxford University Press.

Pesaran, H. M., \& Shin, Y. (1995). An Autoregressive Distributed Lag Modelling Approach to Cointegration Analysis. DAE Working Paper Series, No. 9514, Department of Applied Economics, University of Cambridge .

Pesaran, H. M., \& Shin, Y. (1999). An Autoregressive Distributed Lag Modelling Approach to Cointegration Analysis. In S. Storm, Econometrics and Economic theory in the 20th Century: the Ragnar Frisch Centennial symposium (p. Chapter 11). Cambridge University Press.

Pesaran, H. M., Shin, Y., \& Smith, R. (1996). Testing the Existence of a Long-Run Relationship. DAE Working Paper Series, No. 9622, Department of Applied Economics, University of Cambridge.

Pesaran, M. H., Shin, Y., \& Smith, R. J. (2001). Bounds testing approach to the analysis of level relationships. Journal of Applied Econometrics, 16, 289-326.

Romer, P. M. (1990). Endogenous Technological Change . Journal of Political Economy, 98 (5), 71-102, Accessed on August 4, 2019 from http://pages.stern.nyu.edu/ promer/Endogenous.pdf.

Seng, S. (2014). Causal Relationship between Domestic Saving and Economic Growth. International Journal of Economics and Finance, 6(9), accessed on July 31, 2019 from https://pdfs.semanticscholar.org/87e6/1f75a0924a3f9acb7e41cd31e0ef552cb37b.pdf.

Shimelis, K. H. (2016). Savings, Investment and Growth in Ethiopia. Saarbrucken: Lambert Academic Publishing.

Sims, C. (1980). Macroeconomics and Reality. Econometrica, 48(3), 1-48.

Smith, A. (1776). An Inquiry into the Nature and the Causes of the Wealth of Nations. Accessed on August 4, 2019

from http://www.ultimorecurso.org.ar/drupi/files/Adam $\% 20$ Smith $\% 20 \% 27$ The $\% 20$ Wealth $\% 20$ of $\% 20$ Nations $\% 2$ 7.pdf.

Solow, R. M. (1956). Acontribution to the Theory of Economic Growth. The Quarterly Journal of Economics, 70 , 65-94.

Stiglitz, J. E. (1996). Some Lesson from the East Asian Miracle. The World Bank Research Observer, 11(2), 151177.

Swan, T. W. (1956). Economic Growth and Capital Accumulation. Economic Record, 32, 334-361.

United Nations. (2006). World Economic and Social Survey 2006: Diverging Economic Growth and Development. New York: United Nations.

World Bank. (2016a). World Development Indicators. Washington DC: World Bank.

World Bank. (2016b). World Bank Annual Report 2016: Addressing Critical Global Challenges. Washington DC: World Bank.

World Bank. (2019). World Development Indicators. Washington DC: World Bank 